\title{
FINITE ELEMENT ANALYSIS WITH STATIC AND DYNAMIC CONDITIONS OF SPARE WHEEL CARRIER FOR OH 1526 FABRICATED BY SAPH 440 HOT ROLLED STEEL
}

\author{
Norbertus Krisna Aditya Utomo ${ }^{1, a}$, Lydia Anggraini ${ }^{2, b}$ \\ ${ }^{1}$ Program Studi Teknik Mesin, President University, Jawa Barat, Indonesia \\ anorbertus krisna@yahoo.co.id,
}

\begin{abstract}
Abstrak.
Spare Wheel Carrier adalah komponen yang harus ada di kendaraan tugas berat. Fungsi dari bagian ini adalah untuk menyimpan roda tambahan untuk menangani tusukan yang mungkin terjadi pada ban. Bagian ini biasanya diletakkan di tengah kendaraan untuk menjaga posisi pusat gravitasi kendaraan. Tujuan dari penelitian ini adalah untuk menganalisis kekuatan SAPH 440 sebagai bahan pembuatan Spare Wheel Carrier dari satu perusahaan otomotif. Carrier Roda Spare akan menanggung beban ban pengganti untuk seluruh beban sikliknya. Beban itu sendiri akan menghasilkan tegangan dan regangan pada bagian tersebut, terutama pada sambungan las. Oleh karena itu, analisis harus dilakukan untuk memberikan perusahaan otomotif hasil untuk menentukan perbaikan yang harus dilakukan. Metode yang digunakan dalam penelitian ini menggunakan perangkat lunak CATIA untuk membuat model bagian tiga dimensi. Kemudian, kami mengimpor model ke perangkat lunak ANSYS untuk menganalisis tegangan setara, regangan elastis setara, deformasi arah, dan beban siklik untuk beban tetap, beban hidup, dan beban kejut. Perhitungan menunjukkan bahwa bagian tersebut dapat menahan gaya dari beban tetap, dengan perkiraan beban siklik 70.723 siklus. Tetapi untuk beban hidup, tegangan dan regangan akan terjadi di sekitar kekuatan luluh dan kekuatan limbang offset dan perkiraan beban siklik menurun secara signifikan menjadi 6.358,6 siklus. Lebih lanjut, hasil beban kejut menyatakan bahwa tegangan dan regangan melebihi kekuatan luluh dan mengurangi perkiraan beban siklik menjadi $1.843,9$ siklus. Kesimpulannya, bahan ini terbukti aman untuk digunakan sebagai bahan pembuatan Roda Pengangkut.
\end{abstract}

Kata kunci. pembawa roda cadangan, SAPH 440, tegangan, regangan, deformasi, beban siklik

\begin{abstract}
.
Spare Wheel Carrier is a component that must exists in a heavy duty vehicle. The function of this part is to store additional wheel in order to deal with punctures that might happen to the tire. This part is usually placed in the middle of the vehicle in order to maintain the position of center of gravity of the vehicle. The purpose of this research is to analyze the strength of SAPH 440 as the manufacturing material of the Spare Wheel Carrier from one automotive company. The Spare Wheel Carrier will endure a load of a replacement tire for its entire cyclic load. The load itself will generate stresses and strains in the part, especially in the welding joint. Therefore, the analysis is to be done to provide the automotive company with the result to determine improvement that should be made. The method that is used in this research is using CATIA software to create the three dimensional model of the part. Later, we import the model to ANSYS software to analyze the equivalent stress, equivalent elastic strain, directional deformation, and cyclic load for steady load, live load, and shock load. The calculation shows that the part can endure the force from steady load, with the estimated cyclic load of 70,723 cycles. But for live load, the stress and strain will be happening around the yield strength and offset yield strength and the estimated cyclic load declining significantly to 6,358.6 cycles. Furthermore, the shock load result stated that the stress and the strain are exceeding the yield strength and reduces the estimated cyclic load to 1,843.9 cycles. In conclusion, the material is proven to be safe for usage as the Spare Wheel Carrier manufacturing material.
\end{abstract}

Keywords. spare wheel carrier, SAPH 440, stress, strain, deformation, cyclic load 


\section{PENDAHULUAN}

Salah satu perusahaan otomotif yang beroperasi di Indonesia memproduksi berbagai kendaraan tingkat mewah yang merupakan merek terkenal bagi banyak orang Indonesia. Perusahaan memproduksi mobil penumpang, bus, dan truk, untuk memasok kebutuhan permintaan Indonesia. Tidak hanya dijual di negara ini, beberapa produk juga diekspor ke negara tetangga. Tingkat prestise harus dipertahankan oleh semua aspek karena memajukan standar, termasuk kualitas setiap bagian yang digunakan untuk setiap produk.

Perusahaan cabang Indonesia mengimpor hampir semua bagian dari mitra perusahaan cabang internasional, yaitu dari Brasil, India, dan Spanyol, dan merakit kendaraan di pabrik lokal. Pabrik lokal ini dibagi menjadi dua sub-pabrik, satu untuk merakit mobil penumpang dan yang lainnya merakit enam jenis kendaraan komersial, termasuk bus dan truk. Di antara jenis-jenis kendaraan komersial rakitan, ada satu jenis bus yang mendapat bagian tambahan yang dilokalkan untuk pasar Indonesia saja.

Spare Wheel Carrier adalah bagian yang dibuat khusus untuk satu jenis bus yang diproduksi di Indonesia. Karena berbagai kondisi jalan di Indonesia, kebutuhan roda cadangan meningkat untuk mencegah keterlambatan jadwal agen perjalanan karena kelangkaan bengkel tugas berat. Roda terasa rusak setelah beberapa perjalanan dan perlu penggantian waktu singkat yang siap dipasang. Roda cadangan ini perlu dipasang agar mudah diakses untuk dieksekusi. Dengan demikian, perusahaan memutuskan untuk memenuhi permintaan pasar.

Selain itu, karena bagian pengangkut ini dibuat hanya untuk pasar Indonesia, perusahaan otomotif menyatakan bahwa bagian ini tidak memiliki standar yang disediakan oleh kantor pusat utama perusahaan. Pasar di negara lain tidak memiliki bagian tambahan yang terpasang. Markas utama memungkinkan modifikasi desain untuk mempertahankan tujuan pasar tahunan. Oleh karena itu, penelitian ini adalah salah satu dari banyak upaya untuk memberikan standar bagi perusahaan. Dalam penelitian ini, pembawa roda cadangan akan dianalisis untuk memperoleh spesifikasi minimum yang diperlukan dalam mencegah berbagai kemungkinan masalah yang mungkin timbul di masa depan. Keamanan dan daya tahan akan menjadi perhatian utama dalam seluruh penelitian. Menggunakan data mentah yang diambil dari perusahaan otomotif, penulis akan menunjukkan kekurangan desain yang ada dan memberikan perbaikan jika diperlukan terlebih dahulu.

\section{METODOLOGI PENELITIAN}

\subsection{Spare Wheel Carrier Data}

Penulis mengumpulkan data yang diperlukan di perusahaan otomotif untuk melakukan analisis Pengangkut Roda Cadangan. Pembawa dikencangkan ke bingkai menggunakan mur dan baut dengan momen $58 \pm 45 \mathrm{Nm}$. Bahan yang digunakan dalam pembuatan pembawa adalah SAPH 440 dengan ketebalan $3 \mathrm{~mm}$.

\section{Dimensions}

Untuk mengatur penelitian, penulis disediakan dengan gambar Pengangkut Roda Cadangan oleh perusahaan. Gambar ini juga disertakan dengan dimensi untuk memudahkan penulis dalam merancang model di Catia V5R21.

Pada gambar teknik hasil perbandingan dengan bagian aktual di jalur produksi. Ternyata dimensinya persis sama. Ini berarti bahwa kita dapat menggunakan data ini dalam penelitian kita dan mendapatkan hasil akhir seperti yang diinginkan. Selain menggambar Spare Wheel Carrier, perusahaan otomotif juga menyediakan gambar Hanger Rod. Hanger Rod adalah batang lurus tempat tali pengikat diikat seperti ditunjukkan pada Gambar 2. 


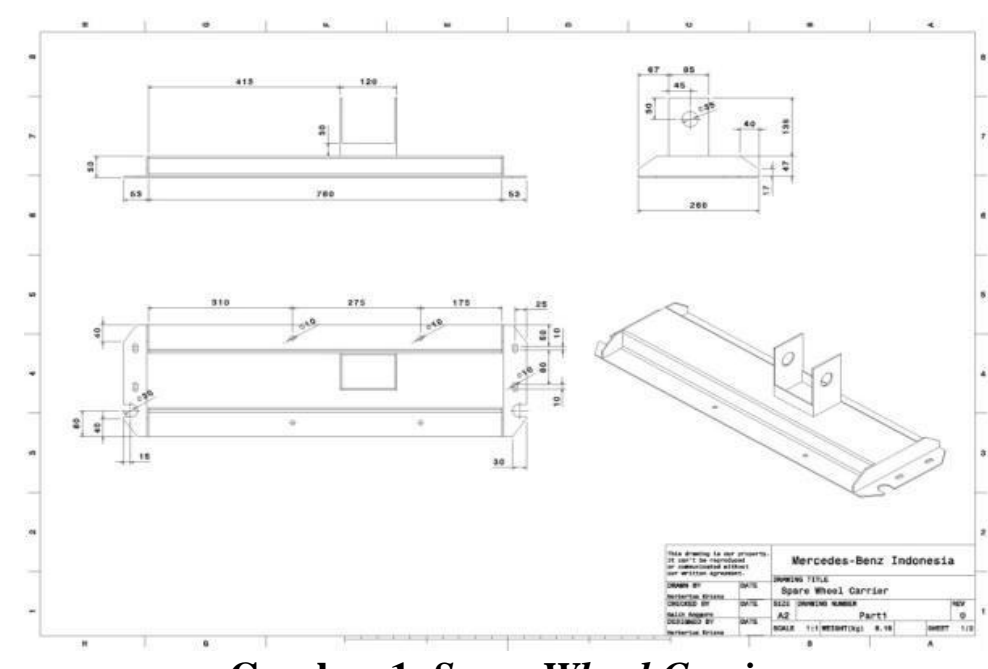

Gambar 1. Spare Wheel Carrier

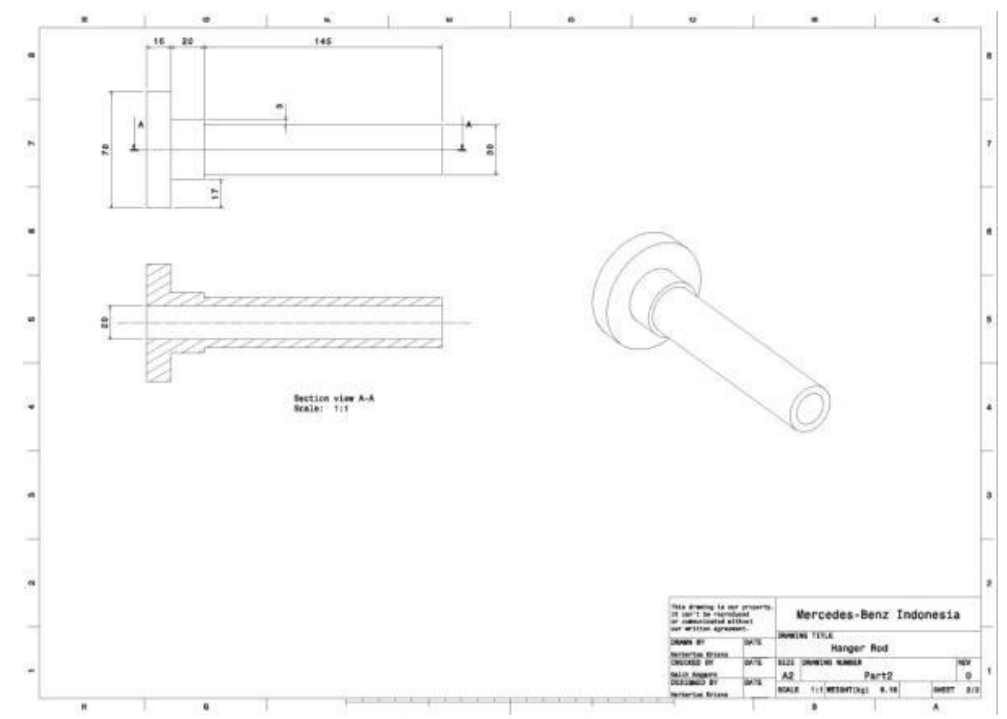

Gambar 2. Hanger Rod

Dalam penelitian ini, Hanger Rod dianggap sebagai cantilever karena bagian ini tidak langsung dilas ke Carrier Roda Cadangan. Oleh karena itu, kita dapat langsung memperoleh hasil yang ditentukan di bagian utama saja.

\section{Material of Spare Wheel Carrier}

Bahan yang digunakan untuk pembuatan Spare Wheel Carrier adalah SAPH 440 dengan ketebalan $3 \mathrm{~mm}$. SAPH 440 steel adalah baja Hot Rolled struktural dalam bentuk pelat, lembaran, dan strip untuk aplikasi struktural mobil. SAPH 440 adalah kelas bahan dengan komposisi kimia fosfor maksimum 0,040 persen dan sulfur 0,040 persen maksimum, dan penunjukannya didefinisikan dalam standar JIS G 3113. JIS G 3113 sendiri merupakan standar bahan Jepang untuk baja Hot Rolled. Berdasarkan JIS G 3113, sifat mekanik SAPH 440 adalah sebagai berikut:

$\begin{array}{ll}\text { Material } & : \text { SAPH } 440 \\ \text { Density } & : 7800 \mathrm{~kg} / \mathrm{m}^{3} \\ \text { Young's Modulus } & : 201 \mathrm{GPa} \\ \text { Poisson's Ratio } & : 0,306 \\ \text { Ultimate Tensile Strength } & : 440 \mathrm{MPa} \\ \text { Yield Strength } & : 305 \mathrm{MPa} \\ \text { Elongation to break } & : 32 \%\end{array}$


Kualitas struktural baja SAPH 440 lebih andal dalam kekuatan tariknya dibandingkan dengan baja SAPH 400. Itu dapat digunakan dalam aplikasi mobil di mana kekuatan lebih dibutuhkan dan bahan tidak gagal di bawah pemuatan melebihi.

\section{Given Loads}

Pembawa akan dimuat dengan satu roda pengganti, dikencangkan ke pembawa menggunakan tali. Roda dikencangkan menggunakan tali untuk memudahkan akses selama proses penggantian. Pelek roda adalah tepi luar roda yang menahan ban. Itu membuat desain lingkaran luar roda di mana tepi bagian dalam dari ban sudah terpasang pada kendaraan seperti mobil. Velg yang digunakan perusahaan otomotif ini berbobot 37 kilogram, sedangkan ban yang digunakan berbobot 58 kilogram. Dengan demikian, beban yang diberikan untuk penelitian ini menggunakan kondisi aktual di lapangan, di mana pembawa dimuat dengan satu ban pengganti yang digembungkan.

$\begin{array}{ll}\text { Mass of Rim } & : 37 \mathrm{~kg} \pm 0.02 \% \\ \text { Mass of Tire } & : 58 \mathrm{~kg} \pm 0.05 \% \\ \text { Total mass (deflated) } & : 95 \mathrm{~kg} \\ \text { Total mass (inflated) } & : 102 \mathrm{~kg} \approx 1000 \mathrm{~N}\end{array}$

\section{HASIL, PEMBAHASAN DAN ANALISA}

Dalam perangkat lunak ANSYS, kita dapat mengimpor file .stp langsung ke meja kerja tanpa penyesuaian desain lebih lanjut. Ini memudahkan penulis untuk menghemat waktu untuk analisis.

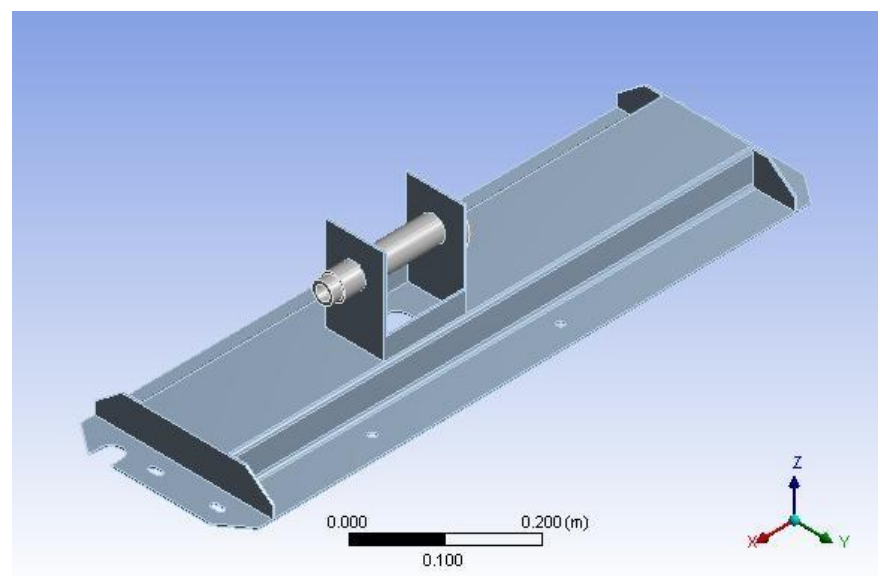

Gambar 3. Spare Wheel Carrier Model

Proyek akan membuka kotak dialog baru di mana kita perlu memasukkan data teknik sebelum kita melanjutkan dengan langkah berikutnya. Data teknik ini berisi jenis bahan dan propertinya. Dalam ANSYS, SAPH 440 dianggap sebagai Baja Struktural. Oleh karena itu, kami memilih Baja Struktural dan kemudian kami menyesuaikan properti agar sesuai dengan sifat SAPH 440.

Perhatikan bahwa nilai-nilai sudah disesuaikan dengan sifat yang sama persis dari SAPH 440. Untuk Elastisitas Isotropik, kita dapat memilih untuk mendapatkan nilai dari data yang diketahui, yang dalam analisis ini Young Modulus dan Poission's Ratio. Di kotak dialog ini, kita juga perlu memastikan bahwa unit sudah benar. Setelah itu, kami mengimpor model rakitan (file .stp) ke kotak dialog geometri. ANSYS akan secara otomatis menentukan geometri bagian yang dianalisis, termasuk kotak pembatas dan properti. 
Tabel 1. Geometry properties

\begin{tabular}{|l|l|}
\hline Object Name & Geometry \\
\hline State & Fully Defined \\
\hline Definition \\
\hline Source & D:ICatialThesis \Carrier.stp \\
\hline Type & Step \\
\hline Length Unit & Meters \\
\hline Bounding Box \\
\hline Length $X$ & $0.866 \mathrm{~m}$ \\
\hline Length $Y$ & $0.26 \mathrm{~m}$ \\
\hline Length $Z$ & $0.185 \mathrm{~m}$ \\
\hline Properties \\
\hline Volume & $1.184 \mathrm{e}-003 \mathrm{~m}^{3}$ \\
\hline Mass & $9.2349 \mathrm{~kg}$ \\
\hline
\end{tabular}

Langkah selanjutnya adalah menentukan koneksi antar bagian. Meskipun ada dua bagian dalam analisis ini, hanger rod tidak akan dimasukkan dalam model karena dianggap sebagai penopang.

\section{Meshing Study}

Setelah model selesai, langkah selanjutnya adalah menentukan mesh yang akan digunakan dalam proses selanjutnya. Untuk menganalisis model, kita perlu menerapkan mesh untuk mencapai kondisi aktual di Carrier Roda Cadangan. Mesh digunakan untuk mendapatkan kedekatan dengan kondisi yang terjadi pada struktur, dalam hal ini adalah Spare Wheel Carrier. Ukuran mesh yang lebih halus akan menghasilkan properti yang lebih detail dan karenanya akan menunjukkan hasil yang lebih akurat.

Masalah yang mungkin terjadi dalam menghasilkan mesh berasal dari keterbatasan alat yang digunakan oleh penulis. Selain itu, ketika ukuran mesh terlalu kecil, perangkat lunak akan membutuhkan lebih banyak waktu untuk melakukan perhitungan. Karena itu, sangat penting untuk melakukan optimasi mesh untuk digunakan jika mesh dan waktu yang dibutuhkan.

Tabel 2. Von-Mises Result of Meshing Study

\begin{tabular}{|l|l|l|l|}
\hline \multirow{2}{*}{$\begin{array}{c}\text { Mesh Size }(m) \\
\text { N }\end{array}$} & \multicolumn{3}{|c|}{ Von-Mises $\left(n \times 10^{8}\right)$} \\
\cline { 2 - 4 } & Nodes 1 & Nodes 2 & Nodes 3 \\
\hline 0.015 & 1.318 & 1.379 & 1.290 \\
\hline 0.014 & 2.786 & 2.914 & 2.725 \\
\hline 0.013 & 3.447 & 3.605 & 3.372 \\
\hline 0.012 & 3.766 & 3.938 & 3.684 \\
\hline 0.011 & 3.871 & 4.048 & 3.787 \\
\hline 0.010 & 3.888 & 4.066 & 3.803 \\
\hline 0.009 & 3.901 & 4.079 & 3.816 \\
\hline 0.008 & 3.911 & 4.090 & 3.826 \\
\hline 0.007 & 3.920 & 4.099 & 3.834 \\
\hline 0.006 & 3.926 & 4.106 & 3.840 \\
\hline 0.005 & 3.931 & 4.111 & 3.845 \\
\hline
\end{tabular}


Tabel di atas menunjukkan hasil studi meshing untuk model Spare Wheel Carrier. Stres Von-Mises yang terjadi adalah hasil dari perhitungan gaya yang diterapkan. Kami menempatkan beban 1000,31 $\mathrm{N}$ ke node berdasarkan beban aktual yang akan diberikan kepada Pengangkut Roda Spare. Setelah kami mendapatkan hasilnya, sekarang kami menempatkan data ke grafik untuk memiliki perbandingan.

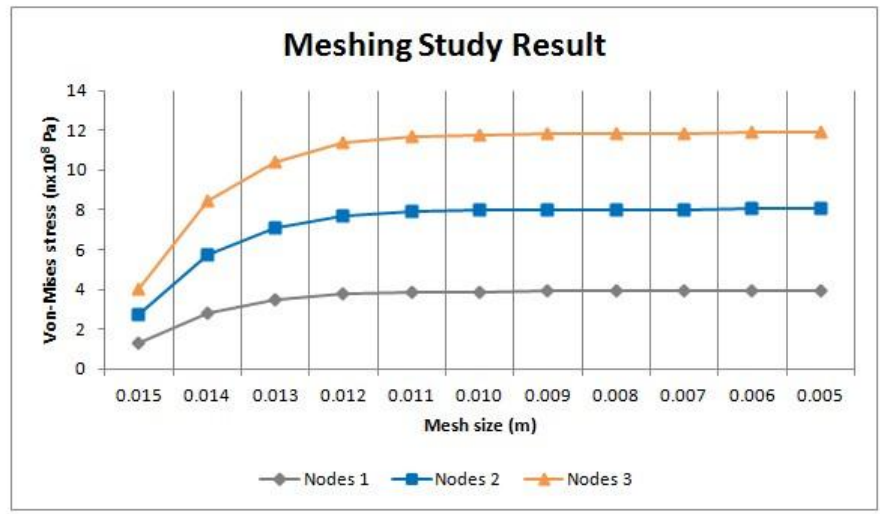

Gambar 4. Grafik hasil meshing study

Dari grafik di atas, kita mulai dari ukuran mesh yang lebih besar hingga yang terkecil. Seperti yang ditunjukkan dalam grafik, garis node 1 mulai meluruskan jika ukuran mesh diatur ke $0,010 \mathrm{~m}$. Hal yang sama juga terjadi pada node 2 dan node 3. Deviasi berkurang secara signifikan pada akhir grafik. Ini berarti bahwa ukuran mesh lebih halus dari $0,010 \mathrm{~m}$ akan memberikan hasil yang tidak akurat untuk seluruh analisis. Dengan grafik ini kita dapat memutuskan bahwa ukuran jala terkecil yang memberi kita data yang akurat adalah $0,010 \mathrm{~m}$. Oleh karena itu, penulis memutuskan untuk menggunakan ukuran meshing ini untuk seluruh analisis.

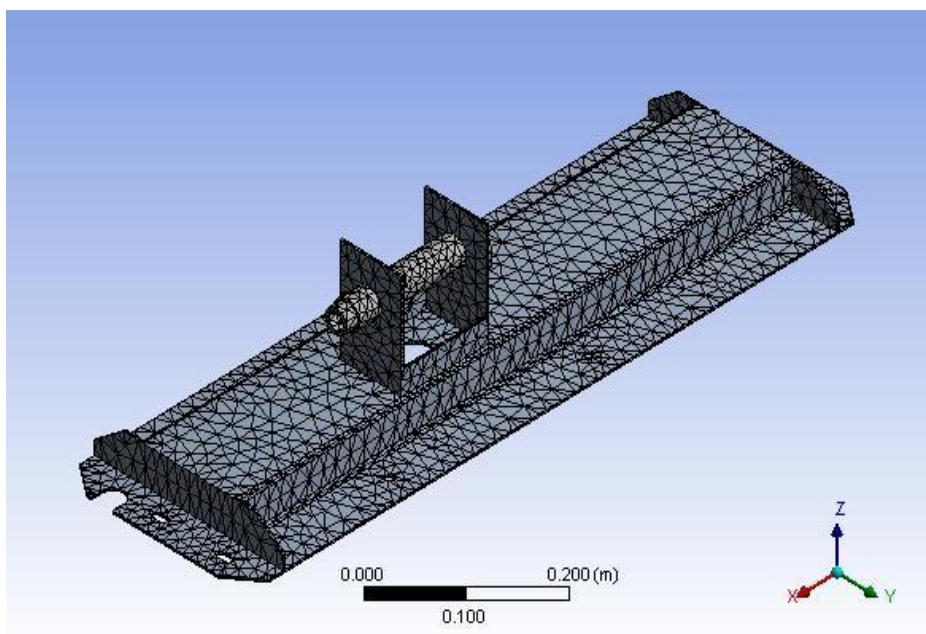

Gambar 5. Mesh visualization

Jenis mesh yang digunakan adalah tetra parabola 10. Tetra parabola meningkatkan derajat keseluruhan kebebasan di dekat area kritis dibandingkan dengan tetra linier. Ukuran mesh ini terbukti menjadi ukuran yang paling tepat sesuai dengan tekanan Von-Mises. Untuk bagian yang dianalisis ini, mesh menghasilkan 27627 node dan 13452 elemen. Angka ini memengaruhi keakuratan hasil akhir dengan kondisi lapangan aktual, di mana bagian tersebut dipengaruhi oleh berbagai jenis muatan. 


\section{Von-Mises Analysis}

Dalam menentukan titik kelelahan yang mungkin terjadi, kita perlu menghitung tegangan dan regangan teknik yang diterapkan pada bagian tersebut. Dengan ANSYS, kita bisa mendapatkan hasil yang bergeser untuk variabel yang berbeda, dalam hal ini gaya yang dimuat. Tetapi sebelum kita memasukkan gaya, kita perlu memilih dukungan tetap pada Carrier Roda Cadangan.

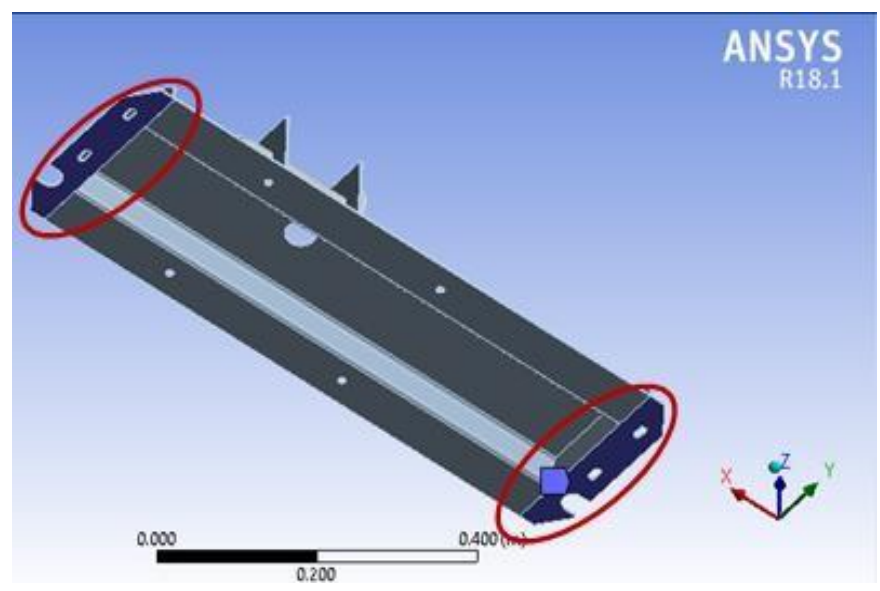

\section{Gambar 6. Fixed supports pada Spare Wheel Carrier}

Untuk analisis pada Spare Wheel Carrier, pendukung tetap yang kami pilih adalah wilayah di bawahnya, di mana ada kontak dari Carrier Roda Spare ke rangka utama kendaraan dan dikencangkan dengan baut. Setelah kami menentukan dukungan tetap, kami melanjutkan untuk menentukan di mana gaya akan diterapkan.

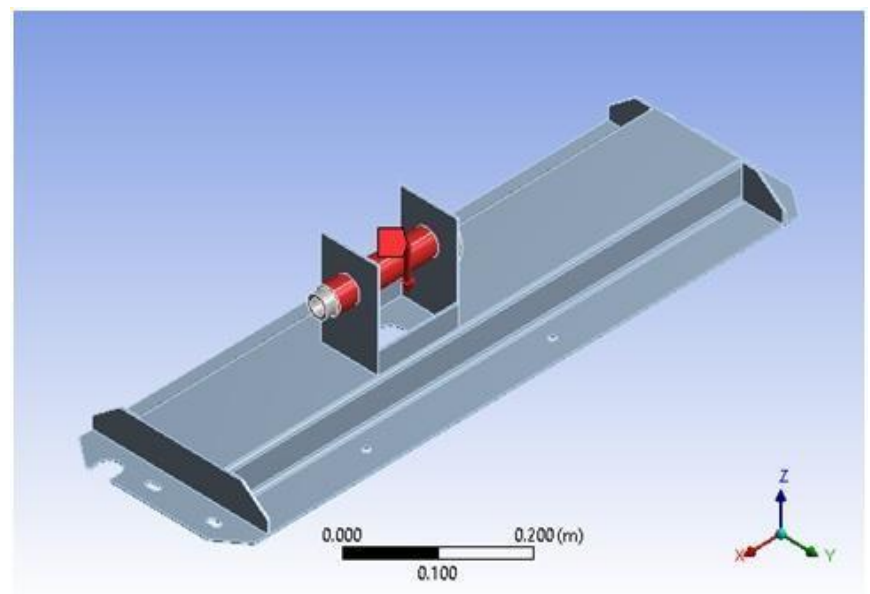

\section{Gambar 7. Force positioning pada Hanger Rod}

Penulis memutuskan untuk menempatkan pasukan di Hanger Rod. Ini karena kebutuhan distribusi gaya yang sama. Jika kita menempatkan gaya di Carrier Roda Spare sebagai gantinya, distribusi tidak akan sama dan output analisis tidak akan mencerminkan kondisi aktual di lapangan.

\section{Cyclic Load Analysis}

Langkah selanjutnya dalam penelitian ini adalah menentukan beban siklik dari Carrier Roda. Ini adalah langkah paling penting karena kehidupan setiap bagian berkontribusi besar dalam keuangan suku cadang. Penulis memilih tipe Fully Reversed karena amplitudo konstan selama analisis. 


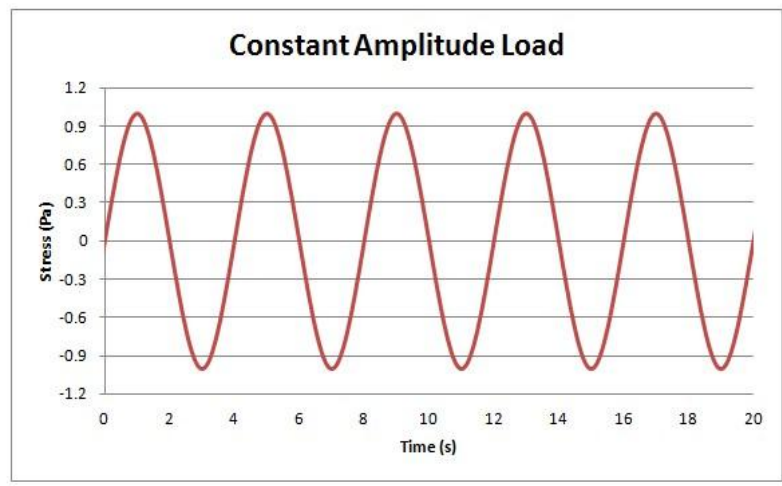

\section{Gambar 8. Fully reversed amplitude load visualization}

Penulis memutuskan untuk memilih Fully Reversed untuk amplitudo karena dibandingkan dengan jenis amplitudo lainnya, hanya amplitudo ini yang memberikan kondisi seimbang pada bilangan positif dan negatif.

Setelah semua data dihitung, kami menemukan bahwa dalam kondisi asli, pembawa terbukti mampu menanggung beban. Beban melewati analisis kekuatan. Beban kondisi asli hanya dimaksudkan untuk kendaraan yang diparkir, sehingga tidak harus diterapkan pada kondisi didorong.

Berbeda dengan kondisi asli, kondisi bervariasi lebih cocok untuk dibahas karena kondisi kedua beban disesuaikan untuk bertahan dalam keadaan aktual. Namun demikian, kami akan melanjutkan analisis kami untuk diskusi untuk masing-masing hasil dibandingkan satu sama lain dan mengamati perbedaan antara hasil.

\section{Von-Mises Analysis}

Bagian pertama dari diskusi adalah tentang efek stres Von-Mises pada Carrier Roda Cadangan. Dari analisis ini kita dapat melihat aspek-aspek yang dipengaruhi oleh berbagai kekuatan terapan.

\section{Equivalent Stress Comparison}

Dari analisis tegangan yang setara, kami dapat mengumpulkan hasilnya dan mengaturnya sesuai dengan jenis beban. Kami juga menempatkan kekuatan luluh dan kekuatan tarik SAPH 440 ke atas meja. Setelah itu kita bisa membuat kesimpulan untuk setiap hasil.

Tabel 3. Perbandingan Equivalent Stress

\begin{tabular}{|l|l|l|l|l|l|}
\hline $\begin{array}{c}\text { Load } \\
\text { Type }\end{array}$ & $\begin{array}{c}\text { Safety } \\
\text { Factor }\end{array}$ & $\begin{array}{c}\text { Maximum Stress } \\
\text { Result }(\mathbf{P a})\end{array}$ & $\begin{array}{c}\text { Yield } \\
\text { Strength }(\mathbf{P a})\end{array}$ & $\begin{array}{c}\text { Tensile } \\
\text { Strength }(\mathbf{P a})\end{array}$ & \multicolumn{1}{|c|}{ Conclusion } \\
\hline Steady & 4 & $1.52 \times 10^{8}$ & & & Safe \\
\cline { 1 - 3 } Live & 8 & $3.03 \times 10^{8}$ & \multirow{2}{*}{$3.05 \times 10^{8}$} & $4.40 \times 10^{8}$ & Safe \\
\cline { 1 - 3 } Shock & 12 & $4.55 \times 10^{8}$ & & & $\begin{array}{l}\text { Exceeding } \\
\text { Tensile Strength }\end{array}$ \\
\hline
\end{tabular}

Dari grafik perbandingan di atas, kita dapat menyimpulkan bahwa untuk tegangan yang setara, tren tegangan cenderung meningkat sesuai dengan beban yang diterapkan. Kondisi aslinya memberikan tekanan yang cukup kecil dibandingkan dengan kondisi yang bervariasi. Beban hidup hampir melebihi kekuatan luluh, sementara beban kejut sudah melampaui kekuatan tarik. Perhatian 
kami adalah beban hidup dan beban kejut di mana keduanya lebih menonjol dan rentan terhadap kerusakan.

\section{Equivalent Elastic Strain Comparison}

Seperti halnya tegangan ekivalen, kita dapat menyusun hasil analisis untuk regangan elastis ekivalen. Untuk regangan elastis, kami menempatkan offset maksimum kekuatan luluh ke atas meja, yaitu 0,002 m / m. Kemudian lagi, kita bisa membuat kesimpulan untuk setiap jenis beban. Dan setelah itu, kami menempatkan tabel ke dalam grafik dan melakukan analisis untuk menentukan hasilnya dan membandingkannya dengan kekuatan hasil offset maksimum.

Tabel 4. Perbandingan Equivalent Elastic Strain

\begin{tabular}{|l|c|c|c|l|}
\hline $\begin{array}{c}\text { Type of } \\
\text { Load }\end{array}$ & $\begin{array}{c}\text { Factor of } \\
\text { Safety }\end{array}$ & $\begin{array}{c}\text { Maximum Elastic } \\
\text { Strain Result }(\mathbf{m} / \mathbf{m})\end{array}$ & $\begin{array}{c}\text { Maximum } \\
\text { Offset }(\mathbf{m} / \mathbf{m})\end{array}$ & \multicolumn{1}{|c|}{ Conclusion } \\
\hline Steady & 4 & 0.0008 & & Still in Elastic Region \\
\cline { 1 - 2 } Live & 8 & 0.0016 & \multirow{2}{*}{0.002} & Almost exceeding Elastic Region \\
\cline { 1 - 2 } Shock & 12 & 0.00245 & & Surpassing Elastic Region \\
\hline
\end{tabular}

Gambar di atas menunjukkan kepada kita hasil dari regangan elastis setara untuk berbagai jenis beban. Kali ini garis tren masih naik dari kondisi semula ke kondisi bervariasi. Menurut grafik, dari empat jenis beban, hanya beban kejut yang telah melampaui kekuatan hasil offset maksimum. Hasil ini berarti bahwa beban tetap, dan beban hidup, masih berada di daerah elastis, sementara hasil beban kejut sudah ada di daerah plastik. Oleh karena itu, deformasi yang terjadi pada model beban kejut yang diberikan tidak akan dapat dikembalikan.

\section{Directional Deformation Comparison}

Analisis terakhir untuk tegangan Von-Mises adalah deformasi terarah, di mana hasilnya menunjukkan pergeseran titik dibandingkan dengan posisi aslinya. Deformasi ini sangat tergantung pada hasil regangan elastis. Kita bisa meletakkan hasilnya di atas meja dan melanjutkan untuk membandingkannya.

Tabel 5. Perbandingan Directional Deformation

\begin{tabular}{|l|l|l|l|}
\hline \multicolumn{1}{|c|}{$\begin{array}{c}\text { Type of } \\
\text { Load }\end{array}$} & $\begin{array}{c}\text { Factor of } \\
\text { Safety }\end{array}$ & $\begin{array}{c}\text { Maximum Directional } \\
\text { Deformation }(\mathbf{m})\end{array}$ & $\begin{array}{c}\text { Conclusion in relation with } \\
\text { Equivalent Elastic Strain result }\end{array}$ \\
\hline Steady & 4 & $4.70 \times 10^{-4}$ & Deformation will be reverted \\
\hline Live & 8 & $9.40 \times 10^{-4}$ & Deformation will be reverted \\
\hline Shock & 12 & $1.41 \times 10^{-3}$ & Deformation will not be reverted \\
\hline
\end{tabular}

Dalam hubungannya dengan perilaku regangan elastis, hasilnya menunjukkan kepada kita bahwa tren juga meningkat dari beban tetap ke beban kejut. Gaya yang diterapkan sangat efektif dalam memindahkan material, terutama dengan model yang memberikan gaya yang bervariasi. Untuk menyimpulkan, satu-satunya model yang tidak dapat kembali ke bentuk semula adalah beban kejut, sementara model beban hidup akan kembali meskipun deformasi cukup besar. 


\section{Cyclic load Analysis}

Bagian kedua dari diskusi adalah tentang analisis beban siklik, di mana model telah diuji dalam simulasi. Dari analisis ini kita dapat melihat hasil mengenai harapan usia bagian.

Tabel 6. Perbandingan cyclic load

\begin{tabular}{|c|c|c|c|}
\hline Type of Load & Factor of Safety & $\begin{array}{c}\text { Minimum cyclic load } \\
\text { result (cycle) }\end{array}$ & $\begin{array}{c}\text { Maximum cyclic load } \\
\text { result (cycle) }\end{array}$ \\
\hline Steady & 4 & 70,723 & $1.0 \times 10^{6}$ \\
\hline Live & 8 & $6,358.6$ & $1.0 \times 10^{6}$ \\
\hline Shock & 12 & $1,843.9$ & $1.0 \times 10^{6}$ \\
\hline
\end{tabular}

Tabel di atas menunjukkan kepada kita bahwa semua model memiliki ekspektasi beban siklik maksimum satu juta siklus. Ini terjadi karena sebagian besar wilayah tidak terpengaruh oleh tekanan Von-Mises. Untuk jumlah minimum beban siklik, jumlahnya berkurang sangat, terutama pada area dekat sambungan pengelasan tempat sudut dibuat. Bahkan penurunan itu terjadi karena beban tetap memiliki penyimpangan yang sangat besar. Semakin banyak ke kiri, perbedaannya berkurang. Ini berarti bahwa beban siklik berbanding terbalik dengan nilai gaya yang diberikan. Beban siklik minimum terjadi di area yang paling dipengaruhi oleh Von-Mises. Ini berarti ada korelasi antara gaya dengan beban siklik.

\section{KESIMPULAN}

Berdasarkan hasil perhitungan dan analisis data yang telah kami lakukan menggunakan perangkat lunak CATIA dan ANSYS, penelitian ini dapat diringkas sebagai berikut:

1. Tegangan Von-Mises maksimum untuk beban tetap masih berada dalam zona aman, sementara untuk beban langsung hampir melampaui tegangan luluh $(3,05 \times 108 \mathrm{~Pa})$, dan untuk beban kejut yang sudah melampaui kekuatan tarik (4,40 x $108 \mathrm{~Pa})$. Retakan mungkin mulai merambat ketika bagian tersebut menahan beban kejut.

2. Regangan elastis maksimum untuk beban tetap adalah $0,0008 \mathrm{~m} / \mathrm{m}$, untuk beban hidup adalah $0,0016 \mathrm{~m} / \mathrm{m}$, dan untuk beban kejut adalah $0,00245 \mathrm{~m} / \mathrm{m}$. Oleh karena itu, hanya beban kejut yang melampaui tegangan hasil offset $0,002 \mathrm{~m} / \mathrm{m}$, sehingga memasuki wilayah plastis dan deformasi tidak akan dikembalikan.

3. Deformasi arah maksimum untuk beban tetap adalah $4,70 \times 10^{-4} \mathrm{~m}$, untuk beban hidup adalah $9,40 \times 10^{-4} \mathrm{~m}$, dan untuk beban kejut adalah $1,41 \times 10^{-3} \mathrm{~m}$. Sesuai dengan regangan elastis, deformasi pada beban kejut bersifat permanen.

4. Beban siklik minimum untuk beban tetap adalah 70.723 siklus, untuk beban hidup 6.358.6 siklus, dan beban kejut adalah 1.843 .9 siklus.

Hasil di atas menyatakan bahwa penggunaan SAPH 440 terbukti aman dan memadai untuk bahan untuk Carrier Roda.

Meskipun perhitungan menyatakan bahwa SAPH 440 aman untuk digunakan sebagai bahan dalam pembuatan, penulis ingin merekomendasikan bahan dengan kekuatan hasil lebih tinggi dan kekuatan tarik untuk mencegah kemungkinan terjadinya kerusakan. Kondisi ini dapat dicapai dengan dua cara, baik mengganti bahan meskipun biaya akan dinaikkan, atau memilih pelat SAPH 440 yang lebih tebal. 


\section{DAFTAR PUSTAKA}

[1] S. R. Schmid, B. J. Hamrock and B. O. Jacobson, Fundamental of Machine Elements, 2014.

[2] W. D. Callister, Material Science and Engineering: An Introduction, 7th ed, John Wiley \& Sons, Inc., 2007.

[3] R. L. Mott, Machine Elements in Mechanical Design, New Jersey: Pearson Education, Inc, 2004.

[4] R. Khurmi and J. Gupta, Machine Design, New Delhi: Eurasia Publishing House (Pvt.) Ltd., 2005.

[5] R. G. Budynas and J. K. Nisbett, Shigley's Mechanical Engineering Design, 9th ed, New York: The McGraw-Hill Companies, Inc., 2011.

[6] N. Subramanian, Steel Structures Design and Practices, Oxford University Press, 2010.

[7] J. Cahoon, W. Broughton and A. Kutzak, Metallurgical and Material Transactions, SpringerVerlag, 1971.

[8] A. Rudskoy, A. Bogatov and D. Nukhov, Metal Science and Heat Treatment, Springer US, 2018.

[9] J. Gliński, J. Horabik and J. Lipiec, Encyclopedia of Agrophysics, Springer, Dordrecht, 2011.

[10] W. K. Schomburg, Introduction to Microsystem Design, Springer-Verlag Berlin Heidelberg, 2015.

[11] J. W. Gooch, Encyclopedic Dictionary of Polymers, New York: Springer, 2011.

[12] B. Heißing and E. Metin, Chassis Handbook, Vieweg+Teubner, 2011.

[13] D. R. White, S. Saigal and S. J. Owen, Engineering with Computers, London: Springer-Verlag, 2005.

[14] T. Lewis, B. von Hohenbalken and V. Klee, Geometriae Dedicata, Kluwer Academic Publishers, 1996.

[15] I. Baker, Fifty Materials That Make the World, Springer, Cham, 2018.

[16] T. Lagoda, Lifetime Estimation of Welded Joints, Springer, Berlin, Heidelberg, 2008.

[17] A. Martini, G. Velter, L. Keer and Q. Wang, Tribology Letters, Kluwer Academic PublishersPlenum Publishers, 2007.

[18] H. Lee and H. Park, Experimental Techniques, Springer International Publishing, 2013.

[19] H. Lian, A. N. Christiansen, D. A. Tortorelli, O. Sigmund and N. Aage, Structural and Multidisciplinary Optimization, Springer Berlin Heidelberg, 2017.

[20] T. Plewa, T. Linde and V. G. Weirs, Adaptive Mesh Refinement - Theory and Applications, Springer, Berlin, Heidelberg, 2005.

[21] L. Anggraini, Fatigue Analysis pada Pegas Daun Jenis SST 74 dalam Aplikasi Industri Alat Berat dengan Pemodelan Metode Elemen Hingga. ROTASI, 2O(2), 118-123, 2018. 